\title{
U.S. Economics Holy Grail - The Great Depression
}

\author{
Frederick Betz ${ }^{1}$ \\ ${ }^{1}$ Graduate School of Management of Technology, Korea University, Seoul, South Korea \& Department of \\ Engineering and Technology Management, Portland State University, Portland, Oregon, USA \\ Correspondence: Frederick Betz, Graduate School of Management of Technology, Korea University, Seoul, South \\ Korea \& Department of Engineering and Technology Management, Portland State University, Portland, Oregon, \\ USA. E-mail: fbetz@venture2reality.com
}

Received: January 15, 2013

Accepted: February 14, $2013 \quad$ Online Published: February 20, 2013

doi:10.5430/bmr.v2n1p74

URL: http://dx.doi.org/10.5430/bmr.v2n1p74

\begin{abstract}
What caused the U.S. Great Depression - money contraction or credit instability or banking fragility or price declines or what? Of course, there was no single 'cause' to the depression. Human society is not a mechanism. All these factors were contributory factors, which in their interaction changed the economic state of the U.S. society from growth in the 1920s into depression of the 1930s. It was stasis changing events which altered the U.S. society the 1929 stock market crash and three successive years of bank panics in 1930, 1931, 1932. Central to this stasis change was an unstable financial sub-system, with a 'fragility of the banks' and an 'instability of credit'. This is one of the big questions about economic theory. How are economies inherently stable or unstable? In a cross-disciplinary framework, we analyze the classic U.S. example of an unstable economy -- the Great Depression. Why did the bank panics follow upon the financial bubble of the stock market? How did these panics set the conditions for insignificant economic recovery after 1933? We use a cross-disciplinary analytic framework to examine the multiple factors in explaining, so as not to be limited by a requirement for a 'single explanation'.
\end{abstract}

Keywords: Economic instability, Bank fragility, Societal dynamics

\section{Introduction}

About the Great Depression, earlier Ben Bernanke (Chair of the U.S. Federal Reserve System in 2012) commented: To understand the great depression is the Holy Grail of macroeconomics. Not only did the Depression give birth to macroeconomics as a distinct field of study, but also - to an extent that is not always fully appreciated - the experience of the 1930s continues to influence macroeconomists' beliefs, policy recommendations, and research agendas." (Bernanke, 1995)

The economic historians, Charles P. Kindelberger and Robert Z. Aliber, summarized some of the arguments: "The monetarist view of the Great Depression is set out in a monumental work by Milton Friedman and Anna Schwartz. (Friedman and Schwartz, 1963) They maintained that the sharp decline in economic activity in the first half of the 1930s was the result of policy mistakes by the Federal Reserve; they focused upon the decline in the money supply from August 1929 to March 1933. . . Peter Temin challenged this monetarist view from a Keynesian point of view. (Temin, 1976) He asked whether the decline in the money supply followed from the decline in spending or whether instead the decline in spending followed from the decline in money supply; he used sophisticated econometrics to choose between the two views. . . Temin concluded that there is no evidence that changes in the money supply between the stock market crash and the British departure from the gold standard in September 1931 caused the depression. . . . Temin's analysis did not provide an explanation of the depression event though it was a strong challenge to the monetarist view. .... (Yet) the debate between the monetarists and the Keynesians ignores the instability of credit and the fragility of the banking system and the negative impacts on production and prices when the credit system became paralyzed because declines in prices of many commodities and goods caused many borrowers to default on their loans - which explains the events in the early stages of the 1929 depression. This view was largely ignored except by Irvin Minsky and Henry Simons." (Kindelberger and Aliber, 2011)

The schools of economists divided over the explanations of the Great Depression. The 'Monetarist School' claimed it was a money-credit contraction acerbated by bad central bank policy for tight money - a process. The 'Keynesian School' claimed it was a structural change due to unemployment created by the industrial contraction caused by the money-credit contraction -- a structure. This division continues. A cross-disciplinary answer is that economies are 
driven both by process and structure. (And from a cross-disciplinary perspective, one notes that the concept of functional-structuralism was popularized in the U.S. sociology by Talcott Parsons, who called 'process' as 'function'. (Parsons, 1937))

Whenever one sees different 'schools' within a discipline, a first instinct often is to ask: which school is right and which is wrong? This certainly is the claim of any school in a social science discipline. My school is right, and your school is wrong. But from a cross-disciplinary perspective, it is often that both schools are partly right and partly wrong. Each school in a discipline may have identified an important but only a partial truth: a process or a structure.

The objective of the research is to see how the explanations about the U.S. Great Depression by the differing schools of economics can be seen as complementary explanations - within a cross-disciplinary meta-framework for analyzing the economic historians' studies about the crisis event.

The structure of the paper follows: first to examine the issues of bank fragility at the time of the 1929 stock market crash, second to review the history of the market crash, third to analyze the crash-event in a societal perceptual space and the societal conditions at the time of the crash within a societal model, fourth to summarize societal change from the crash event, and fifth to examine the depression as a stasis change in the model of the U.S. society before and after the change-events of 1929-1930.

\section{Method}

To study the explanations of the U.S. Great Depression, we use historical economic studies of the time and apply the meta-framework of societal dynamics to analyze the historical events.

\subsection{Bank Fragility --Process}

Banking fragility was not caused by the depression but instead helped bring on the depression. In 2007 with access to new access to data archived in the Federal Reserve System, G. Richardson reviewed the early history of the Depression: "Illiquidity bedeviled banks throughout the depression. Heavy withdrawals played a primary or contributing role in nearly half of all suspensions. Asset problems also bedeviled banks throughout the Great Depression. Slow, doubtful, or worthless assets played a primary or contributing role in over half of all suspensions. The initial banking panic in the fall of 1930 - with its cluster of temporary bank suspensions, bank runs, and collapsing correspondent networks - appears to have been a credit crunch inspired by the collapse of financial conglomerates and propagated by the public's flight from deposits to currency." (Richardson 2007)

The 'slow, difficult, or worthless assets' of the banks were margin loans made to stock brokerages, for the brokerages' customers to purchase stock on margin. In 1929, as the stock prices declined, margin loans were called, stock brokers went bankrupt, and banks which had issued the loans then held vast amounts of stock as collateral illiquidity. These illiquid (unsellable) stocks continued to decline in value as bank assets -- as the stock market continued to decline in 1930 and 1931 and 1932. All the wealth initially put into the stocks purchased on margin became illiquid assets of banks. Liquid wealth was transformed into illiquid assets -- a loss of wealth.

As these asset-values of their stock-collateral declined, these banks had to call in other loans made to other banks and to other customers and businesses. This 'chain reaction' occurred in the collapse of correspondent (bank) networks'. The failed margin-loans triggered a sharp decrease of credit in the U.S. At the same time, the tight-money policy of the U.S. Fed in late 1928, also decreased the money supply. The economic school of 'monetarists' were correct in their explanations that contracting money and credit was the mechanism (process) which spread the stock crash into bank panics into industrial depression.

\subsection{Bank Fragility - Structure}

Banking 'fragility' arose also from banking organization financial structure. The impact of the monetarist process in the U.S. financial system was structurally enlarged by the organization of the financial system - to provide 'leverage'. Richardson wrote: "As Temin and White maintain, a trend of consolidation in the commercial banking industry, as small banks in rural areas left the business, often liquidating involuntarily and after suffering large losses, existed prior to the depression, continued during the contraction, and intensified as the downturn deepened. As Wicker argues, the collapse of the Caldwell conglomerate triggered the initial banking panic in the fall of 1930 . Correspondent networks propagated the panic during the initial weeks, when almost all of the banks which suspended operations were financially or geographically connected to the Caldwell conglomerate. Bank runs radiated outward from these focal events. Heavy withdrawals became the principal form of bank distress and forced hundreds of banks to suspend operations. ... Several smaller correspondent chains, with no connection to Caldwell, imploded in Caldwell's wake. The failure of the Guaranty Building and Loan Association added fuel to the fire." (Richardson, 
2007) The explanation of the deflation was just in a process (contraction of money/credit) but also in how the banking system was organized (infrastructure). Process and infrastructure (function-structure) together explain the occurrence of the depression.

An economic concept, for connecting process and structure in financial systems, was called 'reflexivity' by George Soros. (Soros, 1988) (Soros, 1994) 'Reflexivity' is how speculators 'expectation of future prices' motivates them to buy again and again at higher and higher prices. Reflexivity is the idea that one's expectations about a future can motivate a present action which will help bring about that future really. Reflexivity is an explanatory factor in the occurrence in financial systems of 'credit instability'. The 'expectation' (reflexivity) of speculators impacts prices through their buying/selling something today, based on an expected future price. (If a speculator expects a higher future price, the speculator will buy today; but if the speculator expects a lower future price, the speculator will sell today.) In financial process, the infrastructure of bank networks influences the process through reflexivity in their financial transactions. For example, Richardson wrote: “. . . as Friedman and Schwartz (1963) argued, the failure of the Bank of the United States accentuated depositors' fears and reinvigorated the panic." (Richardson, 2007)

G. Richardson reviewed the scholarship about these banking runs: "Scholars ask three big questions about the banking system during the Great Depression. Why did bank suspensions surge at certain points in time? How bank suspensions affect commercial and industrial activity? Could Federal Reserve intervention have prevented (or did its actions trigger) this crisis?" (Richardson, 2007) These are structural questions about the banking industry: timing, impact, and intervention. In order to understand the importance of timing, one can plot the timing of the bank panics with the decline of industrial production, as shown in Figure 1.

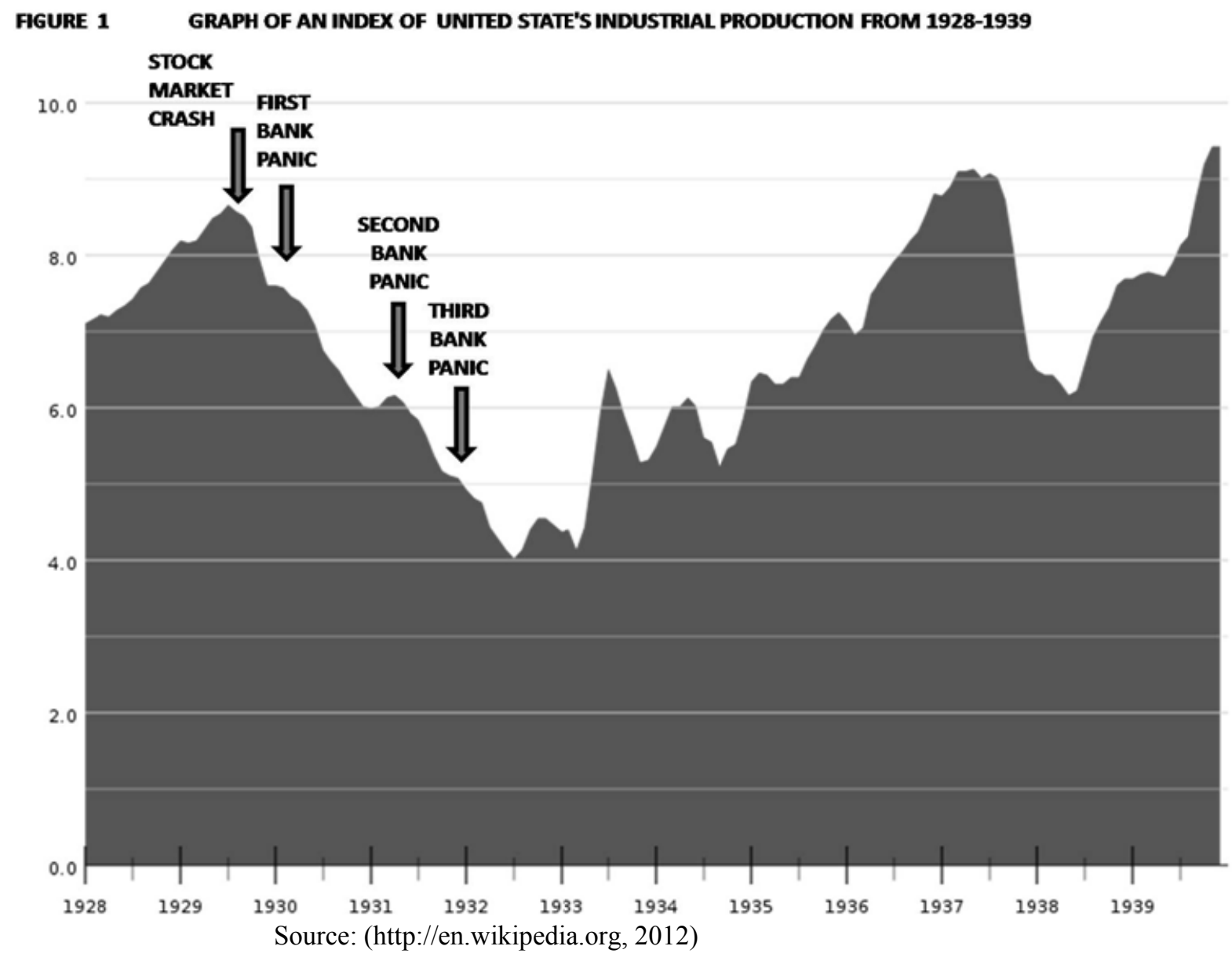

The bank panic of 1930 began an economic recession, but two more years of bank panics (1931 and 1930) turned the recession (business cycle) into a depression (altered stasis of society). About the 1931 panic, Richardson wrote: "As Friedman and Schwartz (1963) contended, illiquidity played a role in the surge in bank suspensions in June of 1931. In that month, runs occurred on banks in Illinois. Examiners reported that heavy withdrawals were the primary cause of almost all of these suspensions. Frozen assets and limited cash reserves contributed to many closures, but none of the banks possessed portfolios which had deteriorated near the point of insolvency.” (Richardson, 2007) 
A 'point-of-insolvency' approached the next year. In 1932, continuing depositors' fears about bank solvency and the banks actual insolvency set off another bank panic: "As Calomiris and Mason (1997) maintain, the Chicago banking panic of June 1932 was due to depositors' confusion about bank asset quality. Examiners reported that for the preponderance of the banks which entered receivership, the primary cause of suspensions was the problem of doubtful and worthless assets.... Declining asset values were the principal cause of bank suspensions. Most banks which closed their doors did so permanently. All were insolvent." (Richardson, 2007)

Bad banking practices had set in motion the chain, in which bank assets became illiquid and this resulted in bank insolvency. The bad practices were risky loans made to stock brokers who had allowed customers to purchase stock on margin. Margin loans by banks leveraged the investments in stocks toward a financial 'bubble'. This is how, Irving Fisher described the Depression: "While any deviation from equilibrium of any economic variable theoretically may, and doubtless in practice does, set up some sort of oscillations, the important question is: Which of them have been sufficiently great disturbers to afford any substantial explanation of the great booms and depressions of history? I venture the opinion . . . that the big bad actors are debt disturbances and price-level disturbances. . . . Over-investment and over-speculation are often important; but they would have far less serious results were they not conducted with borrowed money. That is, over-indebtedness may lend importance to over-investment or to over-speculation disturbances." (Fisher, 1933)

'Over-indebtedness' was created by the loans for margin-stock-purchases, the margin purchases of the 'over-indebted' stock owners. When the stock price fell, the stock owner could not hold onto the stock (without putting up more money responding to an increase in the 'margin call'). They lost the stock and all the money invested into the purchase. Next the stock broker was 'over-indebted', from obtaining a loan from a bank to purchase the 'margined' stock. Next the bank was 'over-indebted', from making a large number of margin-loans to brokers. When the stock market crashed in 1929, many margined-stock owners lost all the wealth they had in the market and some stock brokers went bankrupt. When the stock market continued to crash in 1930, the rest of the margined-stock owners lost their wealth, and the rest of the stock brokers went bankrupt. The margined-stock held as collateral in the banks' assets triggered more bank runs and bank insolvency. In 1933, all the remaining banks in the U.S. were shut down, in a 'bank holiday' called by the new President of the United States. The infrastructure of the banking system of the U.S. had collapsed.

The sequence of three panics impacted industrial production in a series of industrial declines. Yet according to Richardson, there was no scholarly consensus about exactly how. Richardson wrote: "Despite 70 years of analysis, debate persists about the answer to each inquiry. Concerning causes of the banking crises, some scholars conclude that banks failed because the economy contracted. Loan default rates rose. Asset values declined. Deteriorating fundamentals forced banks into insolvency, continuing a process of liquidation that began during the 1920s. Other scholars conclude that a contagion of fear, a flight to cash holdings, and withdrawals en masse drained deposits from banks and pushed financial markets towards collapse. Illiquidity of assets and Federal Reserve inaction exacerbated the credit crunch." (Richardson, 2007) Thus some scholars argued that the banks failed because the economy contracted; others that depositors' expectations turned to fear and withdrew deposits 'en masse'. Which was it? Was bank failure caused by economic collapse? Or was bank failure caused by expectations collapse? What if both? Money-credit was the 'process' connecting banking runs to industrial decline; and bank margin-loans to brokers was the 'structure' connecting the stock market to bank fragility. To see this connection between process and structure, we next look precisely at the history of the stock market crash in 1929.

\section{History -- U.S. Stock Market Crash 1929}

The economic historian, Harold Bierman Jr. summarized: "The 1929 stock market crash is conventionally said to have occurred on Thursday the 24th and Tuesday the 29th of October. These two dates have been dubbed "Black Thursday" and "Black Tuesday," respectively. On September 3, 1929, the Dow Jones Industrial Average reached a record high of 381. At the end of the market day on Thursday, October 24, the market was at 299, a $21 \%$ decline from the high. ... By all accounts, there was a selling panic. By November 13, 1929, the market had fallen to 199 ( $48 \%$ drop). By the time the crash was completed in 1932, with an unprecedentedly large economic depression, stocks had lost nearly 90 percent of their value." (Bierman, 2010)

Bierman described the 'trigger': "While no consensus exists (in 2010) about its precise causes, ... one of the primary causes was the attempt by important people and media to stop market speculators. A second probable cause was the great expansion of investment trusts, public utility holding companies, and the amount of margin buying -- all of which fueled the purchase of public utility stocks, and drove up their prices. Public utilities, utility holding companies, and investment trusts were all highly levered using large amounts of debt and preferred stock. These factors seem to have set the stage for the triggering event. This sector was vulnerable to the arrival of bad news regarding utility regulation. In October 1929 , the bad news arrived and utility stocks fell dramatically. After the utilities decreased in price, margin buyers had to sell and there was then panic selling of all stocks." (Bierman, 2010)

Public expectation of rising prices had driven the stock market higher and higher from 1925-1929. When it collapsed, the leveraging of stocks-purchased-on-margin made the prices fall steeply, destroying wealth: "Margin buying during 
the 1920s was not controlled by the government." (Bierman, 2010) Leveraging was added in the finance of the investment trusts: "By 1929, investment trusts were very popular with investors. These trusts were the 1929 version of closed-end mutual funds." (Bierman, 2010) A closed-end mutual fund is one in which people invested money until a fund goal is met; and then no more investments are allowed into the fund (closed-end); and subsequently the fund invests in something (such as stocks).

Leveraging also occurred in holding companies of public utilities: "Public utilities were a very important segment of the stock market, and even more importantly, any change in public utility stock values resulted in larger changes in equity wealth. In $1929, \ldots$ any change in a public utility's underlying value would result in a larger value change in the market and in the investor's value. ... The holding company typically owned $100 \%$ of the operating companies' stock and both entities were levered." (Bierman, 2010)

Thus in the 1920s stock market, there had been three forms of financial leverage: (1) margin-buying of stock by individuals, (2) leveraged buying of companies by Investment Trusts, and (3) leveraged buyng of utility companies by Utility-Holding Companies. The financing all required bank loans, with only a small amount of actual money invested. The financing of equity growth in the late 1920s was in the form of vast amounts of leverage which would leave banks exposed, when the stock market crashed. For example, in the utility holding companies and investment trusts: "When the large amount of leverage is combined with the inflated prices of public utility stocks, holding company stocks, and investment trust stocks, the problem is . . dramatic. . . A $\$ 1,000,000$ asset is supporting $\$ 1,761,000$ of debt; and the investor's $\$ 38,000$ of equity is very much in jeopardy." (Bierman, 2010) This is a debt-to-equity ratio (leverage) of 46 - forty-six dollars of debt for every one dollar of cash invested.

One can see that the excessive amounts of leveraged financing in the late 1920s had built an unstable U.S. financial structure unstable. It was a large inverted-pyramid of debt resting on only a tiny amount of cash investment. All this inverted pyramid of debt was financed by loans from banks, leaving the bands financially exposed if the market crashed. In 1929, the U.S. stock market crashed.

\section{Societal Perceptual Space Analysis of 1929 Stock Market Crash}

We analyze this event in a societal perceptual space, as shown in Figure 2.

\section{Figure 2 PERCEPTUAL SPACE OF 1930 BANK PANIC}

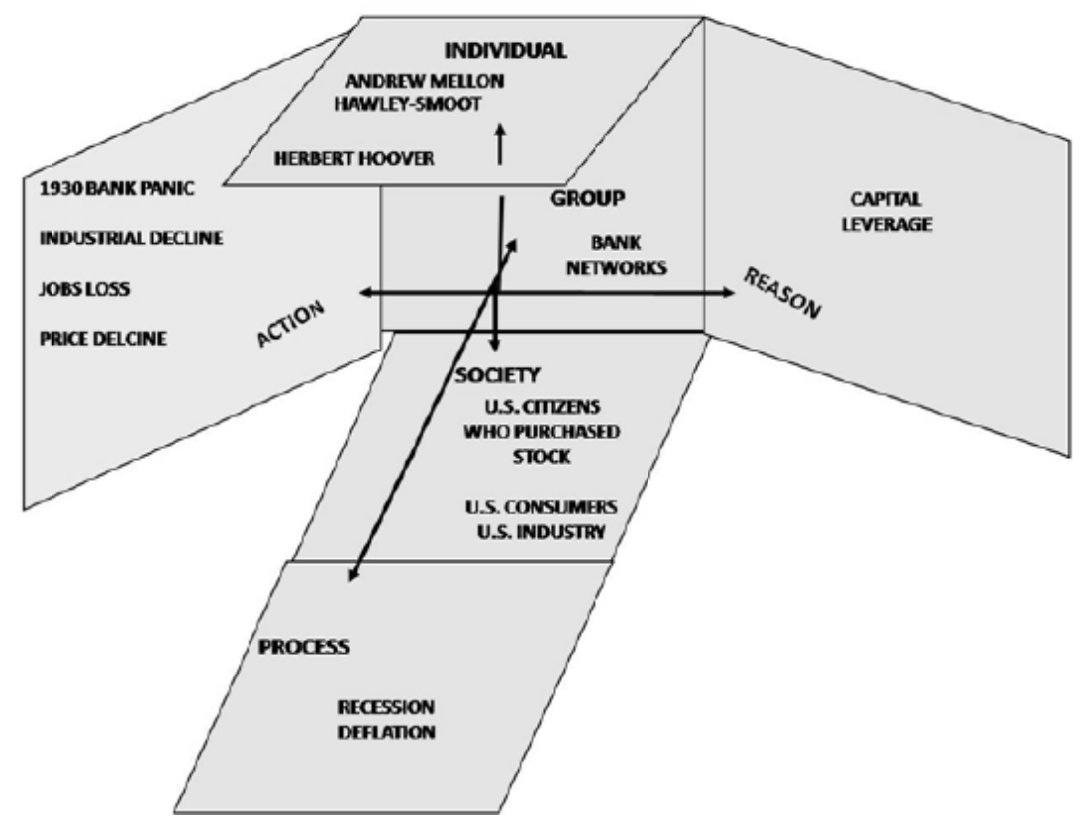

INDIVIDUAL -- Prominent individuals in the U.S. expressed public concern about an over-priced stock market in the spring and summer of 1929.

SOCIETY -- The society of the event was the nation of the United States of America.

ACTION -- The action of the event was the steep decline of the New York Stock Exchange Market in October 1929

REASON -- Stock speculation was the reasoning which had driven the stock prices higher and higher.

GROUP -- Groups involved in the event were Banks, Stock Brokers, Investment Trusts, and Utility Holding Companies. And also involved were the state public utility commissions, concerned about utility company profits. 
PROCESS -- The financial process of 'leverage' was important to the height of the price rise in the New York Stock Market. Stock purchases have been financed by the (1) Banks which had provided stock issues and margin loans, (2) investment Trusts which had purchased companies on leverage, and Utility Holding Companies which acquired utility companies on leverage.

About the financial concept of "leverage", Hyman Minsky identified the importance of leverage to financial speculation. (Minsky, 1982) He identified three kinds of financial use of leverage, as Conservative finance, Speculative finance and Ponzi finance. Conservative finance occurs where borrowers have sufficient cash flow from the leveraged purchase of a capital asset (purchases with loans) to pay both the interest and principle payments during the term of the loan. Speculative finance occurs when the cash flow can handle the interest-portion of the debt payments but not repay the principle; and by the end of the loan, the capital asset must be re-financed or sold. Ponzi finance occurs when the cash flow cannot pay either the interest nor principle payments and must immediately be 'flipped' (resold). Minsky argued that Speculative finance was used in a rapidly growing financial market, moving toward a bubble. Ponzi finance occurred just before the financial bubble burst. (Minsky, 1986) Later George Soros re-emphasized the importance of leverage in financial bubbles and also introduced his concept of 'reflexivity' in the expectations of financial speculators. (Soros, 1988)

About 'expectations' (reflexivity) in the 1929 event, Bierman wrote: "Although no consensus has been reached on the causes of the 1929 stock market crash, the evidence cited above suggests that it may have been that the fear of speculation helped push the stock market to the brink of collapse. It is possible that Hoover's aggressive campaign against speculation, helped by the overpriced public utilities hit by the Massachusetts Public Utility Commission decision and statements and the vulnerable margin investors, triggered the October selling panic and the consequences that followed. An important first event may have been Lord Snowden's reference to the speculative orgy in America. The resulting decline in stock prices weakened margin positions. When several governmental bodies indicated that public utilities in the future were not going to be able to justify their market prices, the decreases in utility stock prices resulted in margin positions being further weakened, resulting in general selling. At some stage, the selling panic started and the crash resulted." (Bierman, 2010) About 'leverage' in the event, Bierman wrote: "A levered investment portfolio amplifies the swings of the stock market. Some investment securities have leverage built into them (e.g., stocks of highly levered firms, options, and stock index futures)." (Bierman, 2010)

In this event of the 1929 stock crash, the U.S. the reflexivity in the public perception of a rising stock market drove the speculative nature of the market: (a) creating a reflexivity (feed-back to reality) in the future pricing of the market after Monday, October 21, 1929; and (b) the steepness of the fall in prices and the non-recovery of the prices occurred because of the large leveraging of loans in the purchase of stocks and in the building of holding companies and investment trusts. We can sketch the dynamics leading up to the event in the societal stasis model in Figure 3.

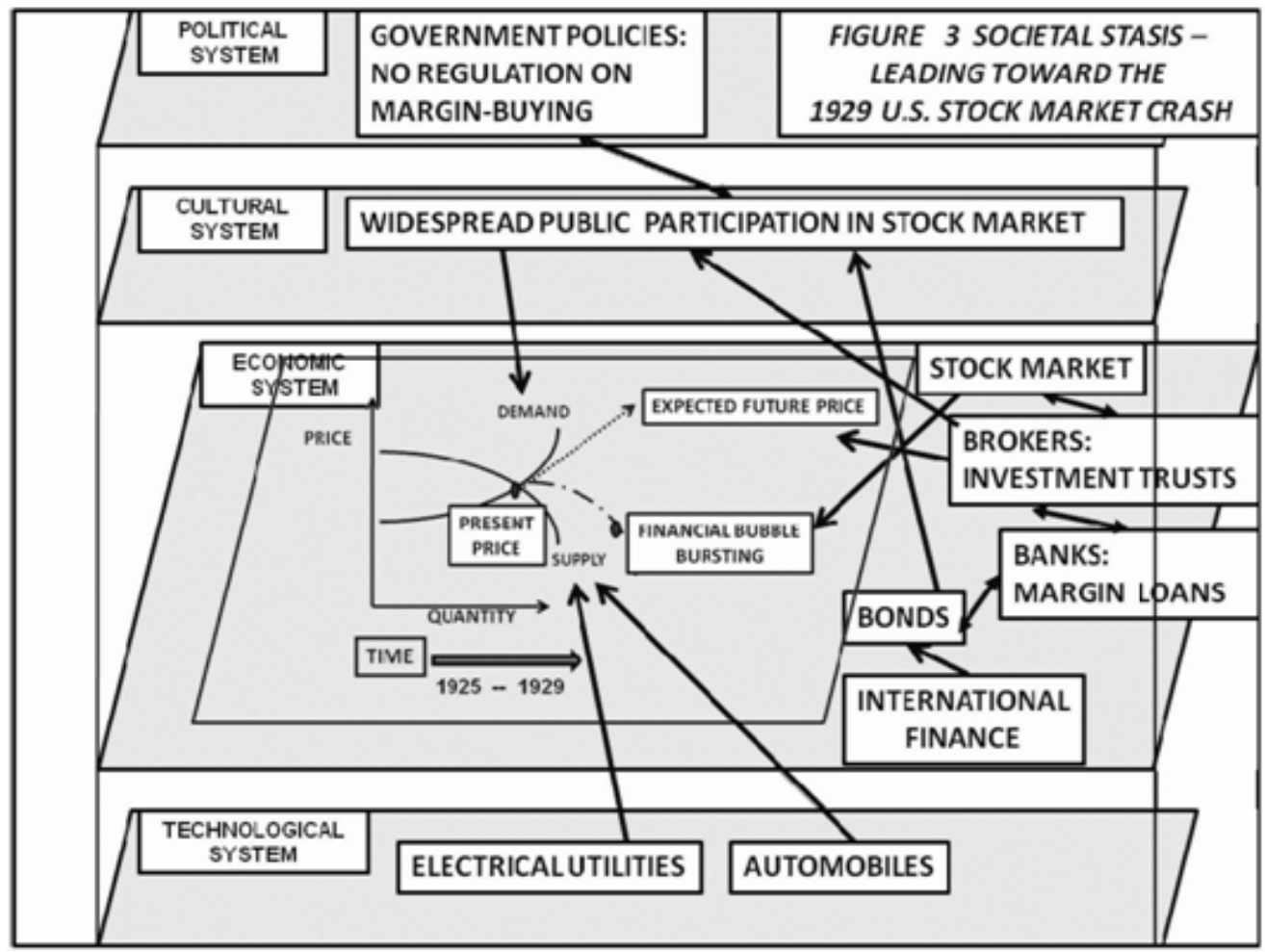


On the political plane, the government policy (of no regulation for limiting the margin percentage on 'margin-loans' by banks) allowed the leverage in market speculation to become very great. In a steep price decline, stock positions had to be liquidated when more money was needed for margin calls.

On the cultural plane, the banks in the 1920s had been actively formulating and selling public stock issued by corporations, broadening public participation in the market. The creation of Investment Trusts facilitated in-direct public participation in the stock market. The creation of public utility holding companies and their stock issues also increased in-direct public participation. Banks also widely solicited investments in foreign government bonds. For example: "From the marble Morgan halls (J. P. Morgan Bank) emerged \$6 billion in securities underwritings between 1919 and 1933 . . . A third was railroad bonds, another third foreign bonds, and the last third corporate bonds. (Chernow, 1990) The cultural change was that the American middle classes began investing in stocks and bonds, which previously had been only invested in by the wealthy.

On the technological plane, rapid industrial expansion occurred in the United States after the end of the First World War and lasting through the 1920s. For example, Randall Parker wrote about that period: "The decade of the 1920s also saw major innovations in the consumption behavior of households. The development of installment credit over this period led to substantial growth in the consumer durables market. Purchases of automobiles, refrigerators, radios and other such durable goods all experienced explosive growth during the 1920s as small borrowers, particularly households and unincorporated businesses, utilized their access to available credit." (Parker, 2010)

On the economic plane, stock prices from 1925 through 1929 climbed toward a speculative disequilibrium point in the summer of 1929, when public perceptions of an over-priced stock market and decline in utility stocks triggered a sharp decline in prices in October -- a stock crash.

In Figure 4, we illustrate the societal dynamics of the stasis of American society in the 1920s (a stasis of industrial expansion and economic growth) that ended suddenly in 1929, after the beginning of the stock market collapse (which would extend through 1933)

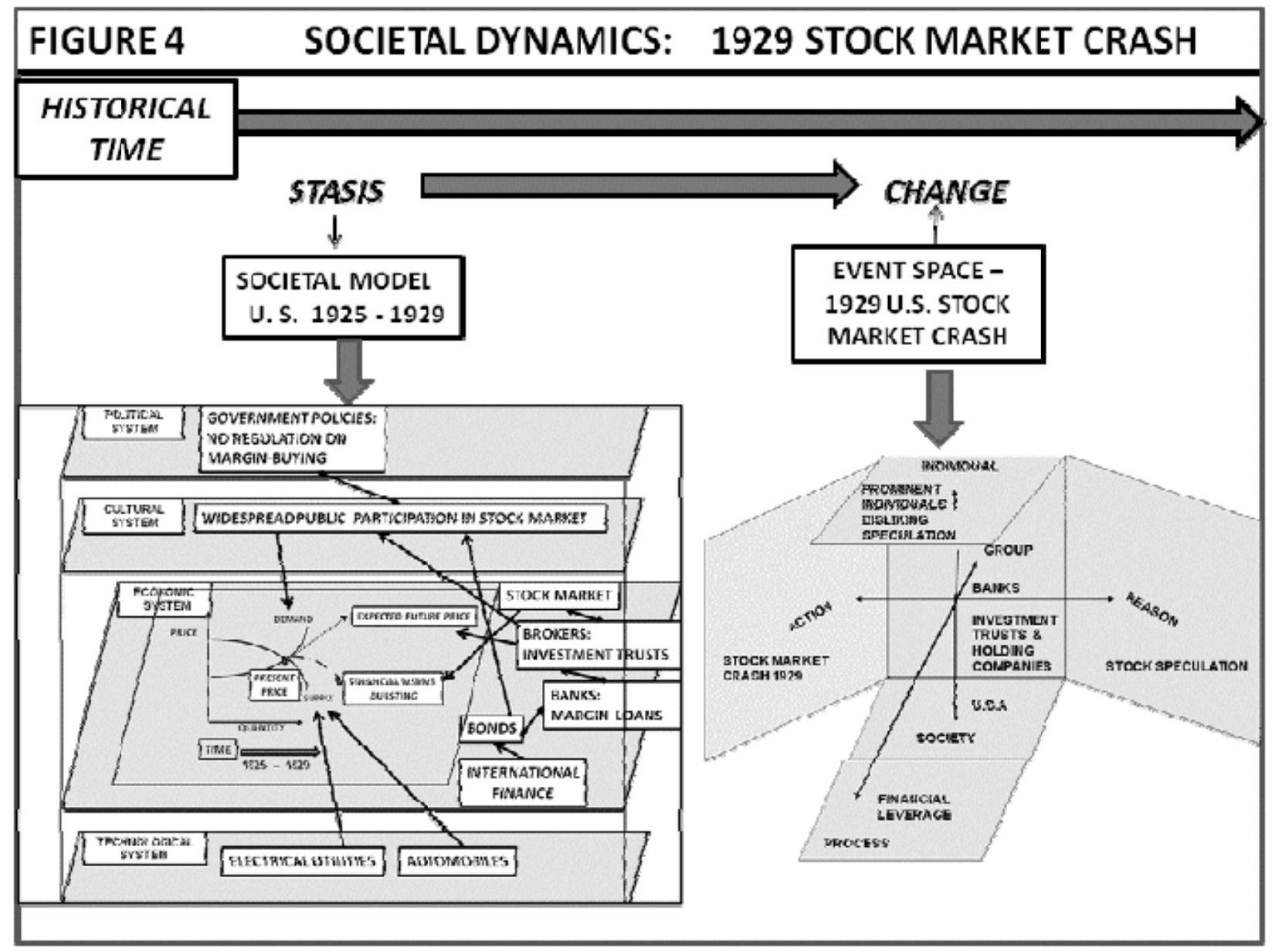




\section{History: U.S. Depression 1930s}

The stock market continued to decline in 1930, 1931, and 1932.Stock positions in the market which had been purchased on margin were being wiped out. The continuing decline in bank assets (from margined-stock held as collateral) created the sequence of bank runs. Bank runs occur when banks are illiquid and/or insolvent, and depositors demand immediate withdrawal of deposits. If one plots the percentage of bank failures due to insolvency and compares this to the drop in stock market prices, one can see a temporal correlation between stock prices and bank failures due to insolvency, Figure 5.

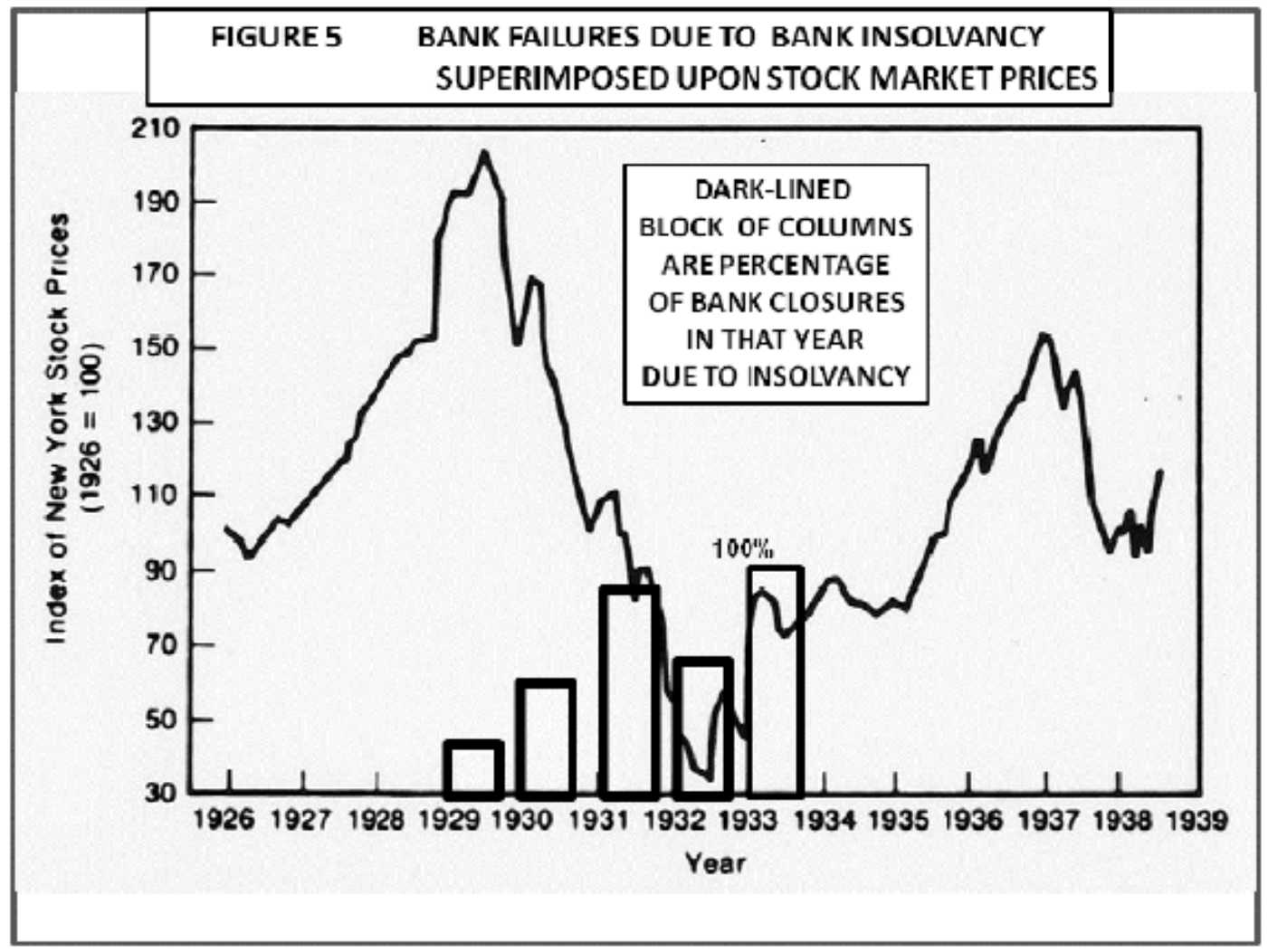

Source of Bank Closures Data: (Richardson, 2007)

The percentage of bank failures due to insolvency increased each year from 1929 to 1933, as the stock market had continued to decline. It was a continuing series of events which culminated in all banks failing. First there was the stock market crash in 1929, triggering the 1930 bank failures -- which began the depression.

The next year in 1931, bank runs occurred again. Randall Parker wrote: "In May, the failure of Austria's largest bank, the Kredit-anstalt, touched off financial panics in Europe. In September 1931, having had enough of the distress associated with the international transmission of economic depression, Britain abandoned its participation in the gold standard. Further, just as the United States' economy appeared to be trying to begin recovery, the second wave of bank failures hit the financial system in June and did not abate until December. In addition, the Hoover administration in December 1931, adhering to its principles of limited government, embarked on a campaign to balance the federal budget. Tax increases resulted the following June, just as the economy was to hit the first low point of its so-called 'double bottom' ...." (Parker, 2010) And this second wave of bank runs had additional and serious impacts upon the economy: "The results of these events are now evident. Between January and December 1931 the industrial production index declined from 78 to 66 , or 15.4 percent, the consumer price index fell 9.4 percent, the nominal supply of M1 dipped 5.7 percent . . . by the December output, the money supply, and the price level were all on negative growth paths that were dragging the economy deeper into depression." (Parker, 2010)

The third bank run in 1932 finally collapsed the economy: "The economic difficulties were far from over. The economy displayed some evidence of recovery in late summer/early fall of 1932. However, in December 1932, the third and largest wave of banking panics hit the financial markets; and the collapse of the economy arrived with the business cycle hitting bottom in March 1933. Industrial production between January 1932 and March 1933 fell an additional 15.6 percent. ..." (Parker, 2010)

All the bank panics traced back to the 1929 stock market, which had left a large amount of stock-collateral in the banks from their earlier margin-loans. When bank assets declined in value below bank liabilities, the banks became 
insolvent. As we previously noted, Richardson summarized this time: "For the remainder of the contraction (1930-33) . . . declining asset values were the principal cause of bank suspensions. Most banks which closed their doors did so permanently. All were insolvent." (Richardson, 2007) When the market hit bottom in 1932, the market had lost 83\% of its value. Later in 1933 and 1934, some recovery occurred; but even then the market still had lost $60 \%$ of its value. A vast amount of wealth was lost; and a vast amount of capital was gone from the American economy in the 1930s.

In physics, matter and energy are conserved in all physical events. Not so in society. Society is not describable in such a 'positive science' like physics. In a society, there is no law of the conservation of money and wealth. Money and credit and wealth can be created and can be destroyed. Money and credit are not mechanisms but functionalities. And this is why bank panics matter - the abrupt loss of capital in an economy. Capital is not always transferred from a loser to a winner in an economic transaction; in a bank panic, capital can be absolutely lost - no winners, but all losers. Money is functionally a social agreement, and social agreements can be broken by-all-and to-all when a social structure for agreements collapses.

As industrial production fell, unemployment increased and consumption decreased; and by 1933, the U.S. depression was set and frozen. Then President Franklin Roosevelt succeeded President Herbert Hoover; and Roosevelt closed the banks for a 'bank holiday' and ordered the U.S. Federal Reserve System off the 'gold standard' (promising to redeem dollars in gold bullion). The economy began a slow and modest recovery. But another recession occurred in 1938 when President Roosevelt cut government spending. In 1941, U.S. rearmament began, and government spending grew. And in December U.S. entered World War II. The country never really recovered from the full depression until the beginning of World War.

When banks could no longer make loans and issue credit (either by cutting back on loan business or simply by failing), then businesses and industries which depended upon bank credit for their operations also had to cut back on business or failure. Business 'down-sizing' and business failures resulted in job losses, increasing national unemployment. This is shown in Figure 6, wherein unemployment rose from the summer of 1929 at $5 \%$ to $10 \%$ in 1930 and to $20 \%$ in 1930 and was $22.5 \%$ in 1935 . But the impact upon employment of people in cities was even more severe. Up until 1930, 79\% of the population had earlier been employed in industry. When unemployment reached $22.5 \%$ in 1932 , this meant that about $27.5 \%$ of the city folk were unemployed (assuming the farmers remained employed on the farm, if they had not lost their farm).

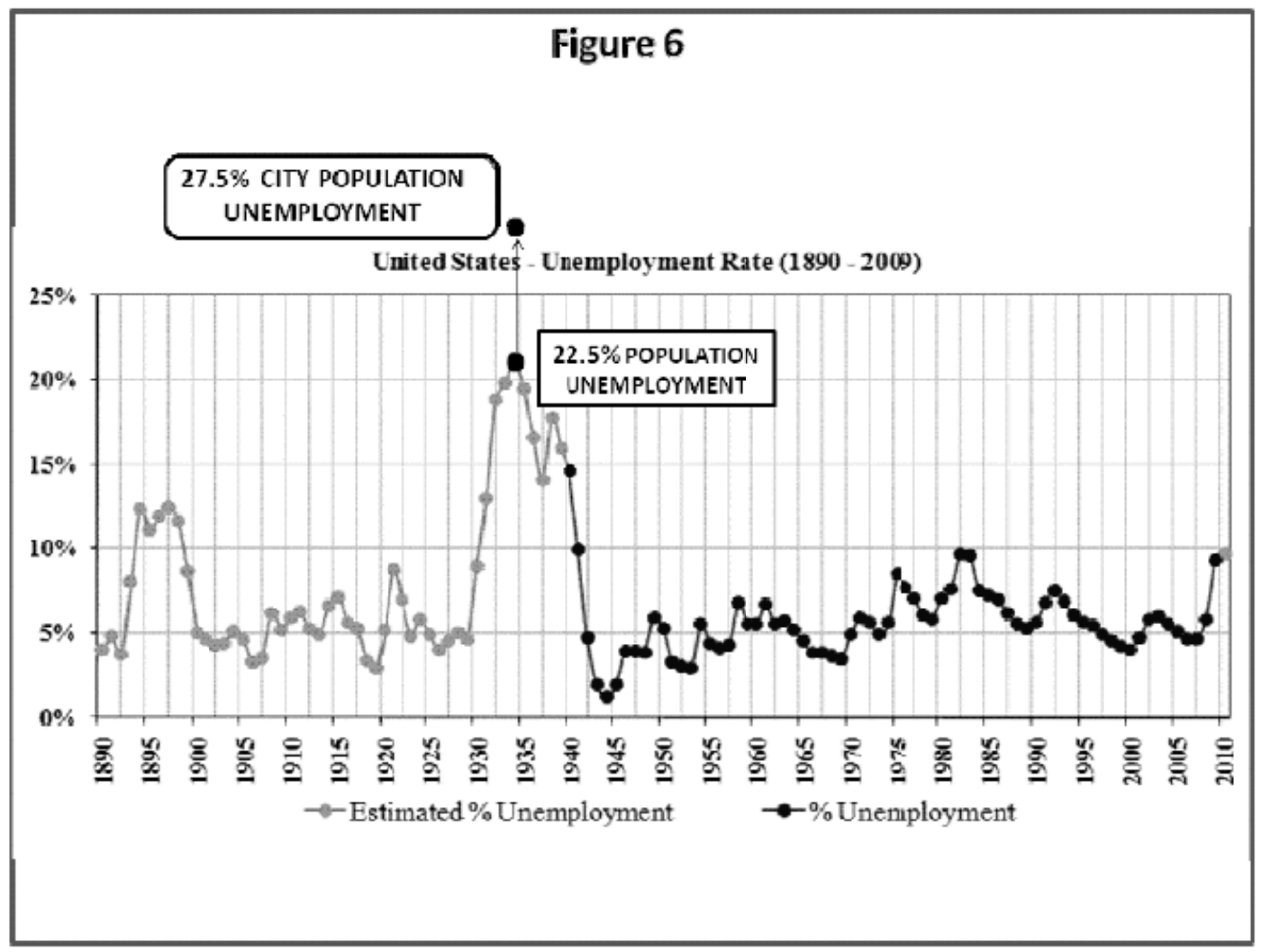

Source: (http://.en.wikipedia.org, Unemployment in the United States, 2010) wherein Estimated U.S. Unemployment rate from 1890-2010. (1890-1930 data are from Romer. 1930-1940 data are from Coen. 1940-2009 data are from Bureau of Labor Statistics.) 
This was a big structural change in a society -- to have more than a quarter of the city folk out of work. This stasis change after 1929 altered the U.S. economy into a state of 'structural unemployment' -- when at least one-quarter of a working population is unemployed in a nation.

As jobs were lost, consumer consumption fell when families of the unemployed had no income to purchase necessities. Then prices in commodities also fell as consumption fell. This followed in the pattern of the classical supply-demand equilibrium pricing theory of economics. One can see this for agricultural prices, as shown in Figure 7.

\section{FIGURE 7}

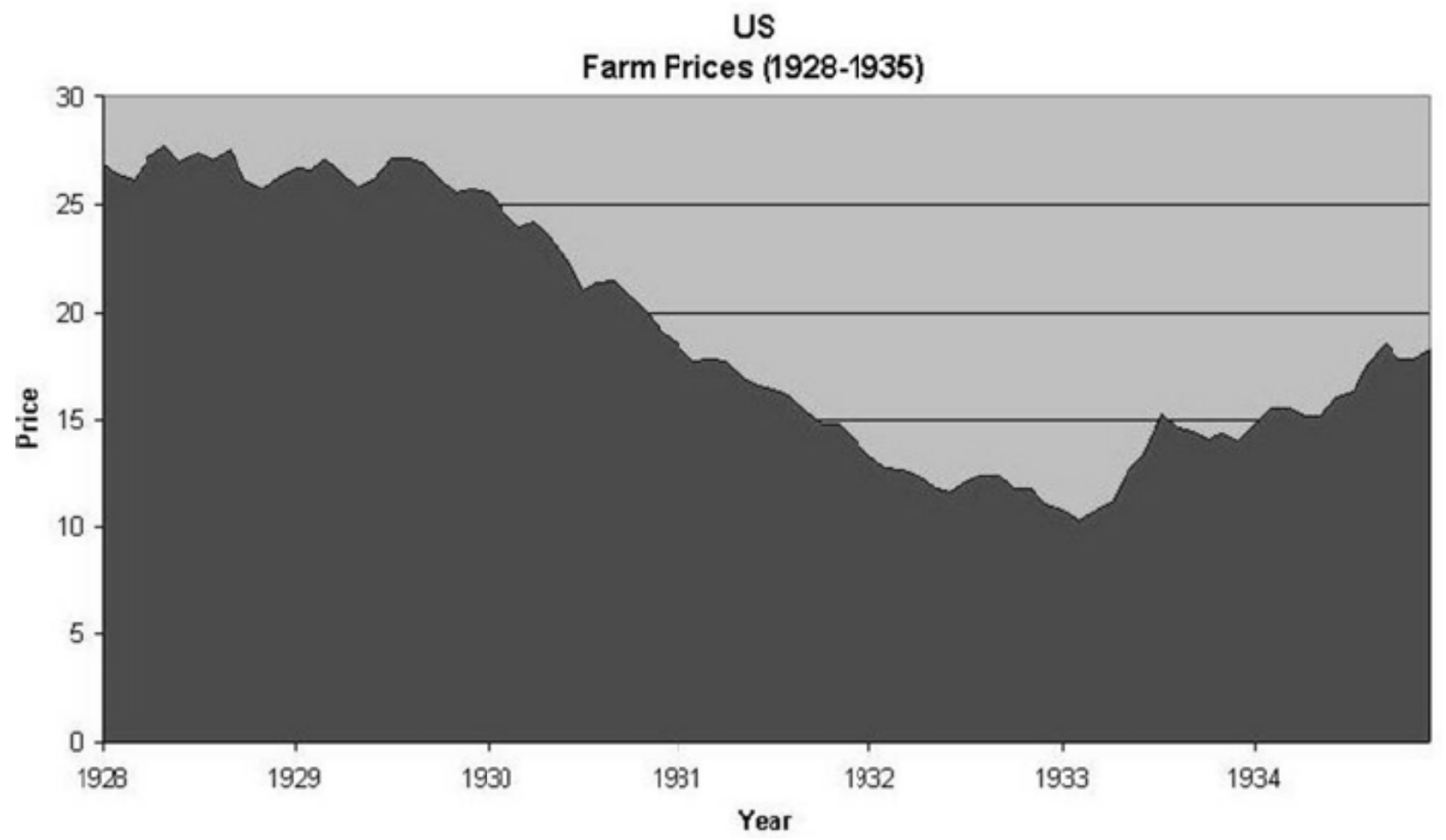

Source: (http://en.wikipedia.org/wiki/File:US_Farm_Prices_\%281928-1935\%29.JPG, 2012)

After the stock market crash in the fall of 1929 down to February 1933, there a steady decline in agricultural prices, down by nearly $62 \%$. It is likely that during this time, 'supply' (agricultural production) may not have changed much, since then most farming then was still family farming. Farming families needed to grow as much product as they could to support their families, especially during those years of declining prices (deflation). Agricultural supply was probably fairly constant over the early years of the 1930s, and the price decline was due to a decline in demand. (There was a Western drought in the late 1930s, which decreased supply, but this did not occur until 1937.)

Increasing unemployment lowered demand for consumer products, as unemployed families lost income to buy consumer necessities. The economic historian Frank G. Steindl expressed the cultural significance of that unemployment: "The Great Depression has two meanings. One is the horrendous debacle of 1929-33 during which unemployment rose from 3 to 25 percent as the nation's output fell over 25 percent and prices over 30 percent, in what also has been called the Great Contraction. A second meaning has the Great Depression as the entire decade of the thirties, the anxieties and apprehensions for which John Steinbeck's The Grapes of Wrath is a metaphor. ..." (Steindl, 2010)

\section{Stasis Change: US. Society Before and After 1929.}

In Figure 8, we model the stasis of society in the U.S. in the 1920s, before 1929. 


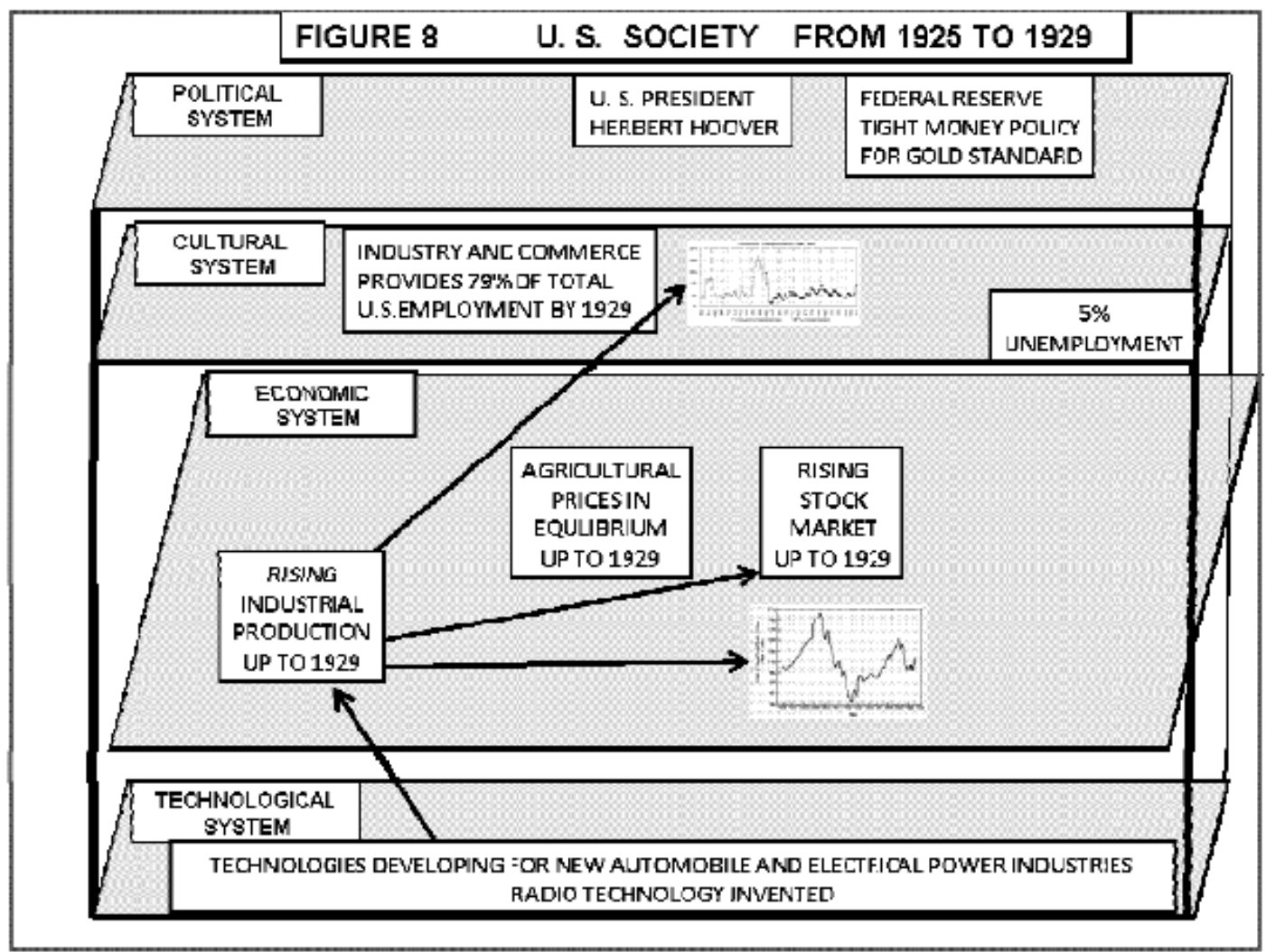

We see the structures of the society from 1925-1929:

-- On the Economic Plane there was a rising stock market (rising capital), rising industrial production (rising economy), and stable agricultural prices (supply-demand equilibrium pricing); the Federal Reserve had held interest rates to banks low to make bank credit easy to obtain at low interest rates.

--- On the Cultural Plane, there was low unemployment in the cities (relatively full employment) and a movement of the people from farms to cities (with most population, 79\%, living in the cities);

-- On the Technological Plane, technologies of automobiles and electrical power utilities were being developed and implemented;

-- On the Political Plane, in 1929 President Herbert Hoover acted to discourage speculation, ordering the Fed to reverse its stimulus policy and raise its interest rates to banks.

The succession of bank panics and accompanying industrial contraction together fatally altered the structure of U. S. society. Instead of a bank panic triggering an economic recession, the three panics triggered an economic depression. In an economic recession, the economic structure remains the same but a business cycle occurs from expansion to contraction to expansion again. But in an economic depression, societal structure alters and the normal business cycle does not run as before.

Irving Fisher had earlier made this distinction: "The old and apparently still persistent notion of 'the' business cycle, as a single, simple, self-generating cycle (analogous to that of a pendulum swinging under influence of the single force of gravity) and as actually realized historically in regularly recurring crises, is a myth. Instead of one force there are many forces. Specifically, instead of one cycle, there are many co-existing cycles, constantly aggravating or neutralizing each other, as well as co-existing with many non-cyclical forces. In other words, while a cycle, conceived as a fact, or historical event, is non-existent, there are always innumerable cycles, long and short, big and little, conceived as tendencies (as well as numerous noncyclical tendencies), any historical event being the resultant of all the tendencies then at work. .. The innumerable tendencies making mostly for economic dis-equilibrium may roughly be classified under three groups: (a) growth or trend tendencies, which are steady; (b) haphazard disturbances, which are unsteady; (c) cyclical tendencies, which are unsteady but steadily repeated. . There may be equilibrium which, though stable, is so delicately poised that, after departure from it beyond certain limits, instability ensues ... such a disaster is somewhat like the 'capsizing' of a ship which, under ordinary conditions, is always near 
stable equilibrium but which, after being tipped beyond a certain angle, has no longer this tendency to return to equilibrium, but, instead, a tendency to depart further from it." (Fisher, 1933)

Like this simile, the economic U.S. ship-of-state had capsized by 1933. It was not to be righted again until the war years of 1941-46. But by then that 'ship' was a different U.S. society. We can describe this kind of transition a change of stasis in the society

The 1930s depression lasted a decade from 1930 to 1940, and the 1982 depression lasted eight years. Depressions are serious changes in the state of a society -- not merely a business cycle of a recession. That level of unemployment in a society alters is socio-economic structure and its consumption patterns. Next in Figure 9, we can model the same society but from 1930 to 1940 , seeing a different societal structure.

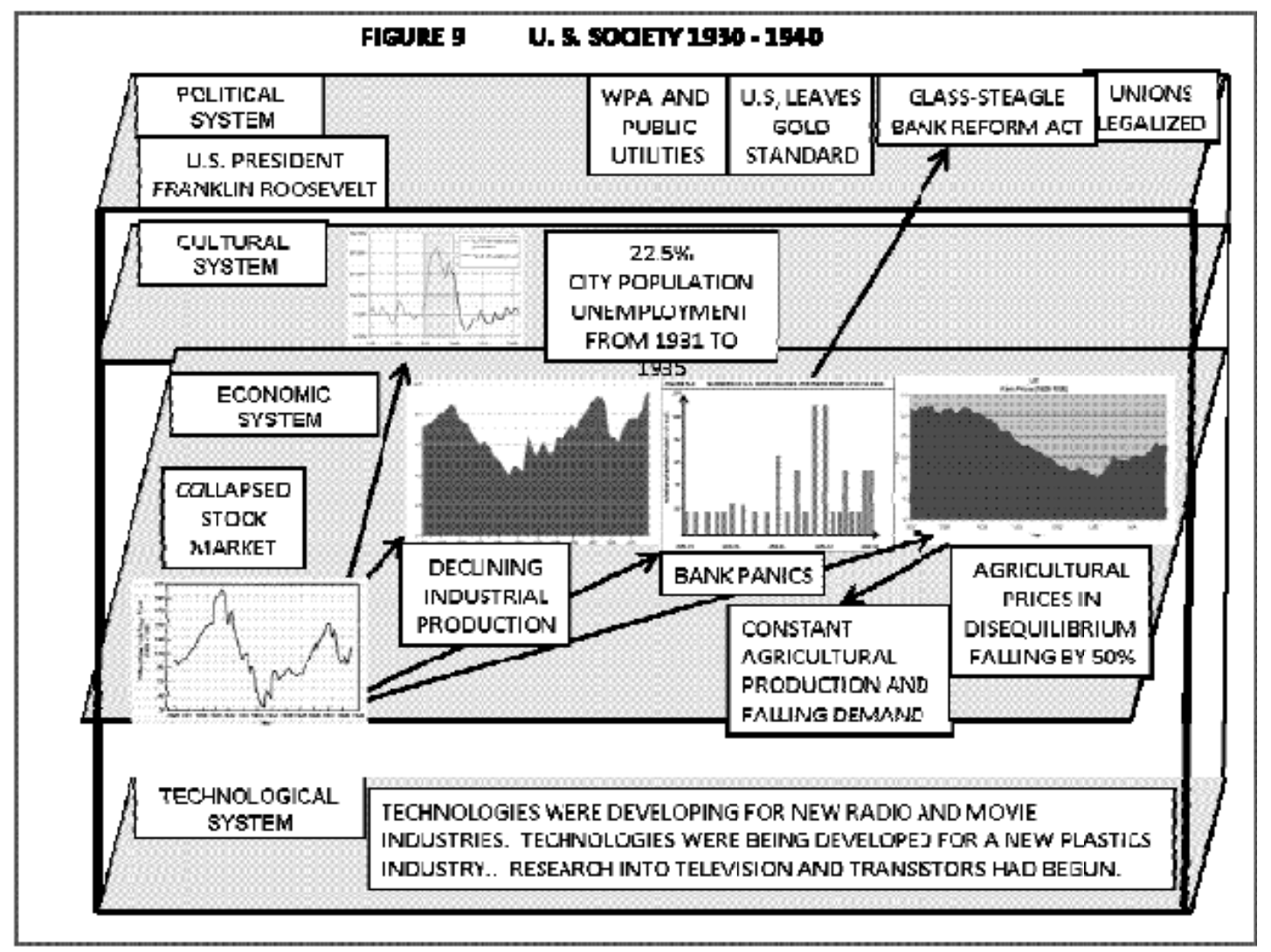

We see the structures of the society from 1930-1940:

-- On the Economic Plan, there was a collapsed stock market and a series of bank runs (lost capital), declining industrial production (depressed economy), and much lower agricultural prices (supply-demand dis-equilibrium pricing);

--- On the Cultural Plane, there was high unemployment in the cities (one quarter of the population out of work));

-- On the Technological Plane, new technologies of plastics was being developed but not yet industrially implemented. Technologies and new industries of radio and movies were being developed. Research into television and transistors had begun.

-- On the Political Plane, after 1933, Franklin Roosevelt was the new President. A bank holiday was called, and then new bank regulation was enacted (Glass-Steagle Act) separating investment banking (bond and stock issuance and trading) from commercial banking (savings deposits and loans). U.S. species (money) left the 'gold standard' (dollars were no longer redeemable by gold from the Federal government). Works projects were begun (WPA) to provide some jobs. Federal utility dams were built to provide electricity to rural areas (e.g. Tennessee Valley Authority in the east and Hoover dam in the west). Labor unions were legally recognized by the government (National Labor Relations Act). 


\section{Results}

In Figure10, we compare these two societal models before and after the change-event of the 1929 stock market crash. Therein one can picture societal models changed by the historic event.

\section{FIGURE 10 SOCIETAL DYNAMICS: DEPRESSION TRANSFORMANTION OF U.S. SOCIETY 1930 -1940}

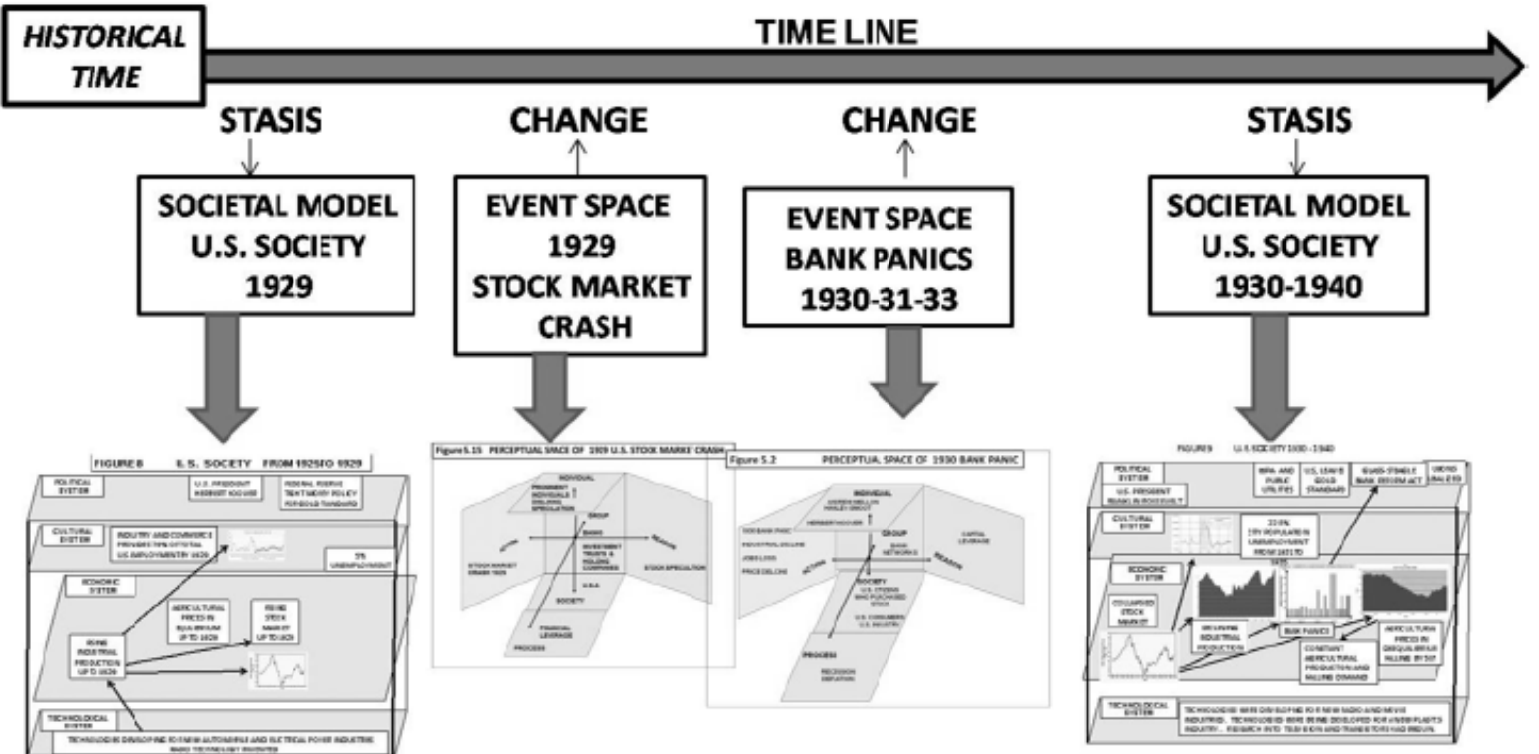

There were three big social structural changes between American society before and after 1929:

-- The population structure changed among the social classes $(21 \%$ farmers and $66 \%$ employed city folk and $5 \%$ unemployed city folk) to (21\% farmers and $44 \%$ employed city folk and $27 \%$ unemployed city folk). This great increase in the unemployed working class greatly decreased demand for goods and services and also destroyed many families (a quarter of the entire U.S. population affected). This is a huge societal change -- in cultural structure (classes) and in economic structure (consumer demand).

-- The capital structure (societal wealth) declined by $80 \%$ of the capital in 1929 (a collapse of $80 \%$ of stock values from 1929 to 1933, and back up to $40 \%$ of their value in 1934-35). Societal wealth (economic wealth) exists in the form of species (money), credit (loans), and liquid assets (sellable stocks, bonds, property). Loans were called in the bank runs of 1930, 1931 and 1932.

-- This reduction of wealth impacted the industrial structure in America; as from 1930 to 1932, banks had to call loans. These loan calls reduced credit to businesses. Some businesses lacking credit went bust (bankrupt); others survived by reducing production and firing workers. The industrial production' index' (Figure 7) fell from 8.5 in 1929 to 5.5 in 1933, recovering a bit to an average of 6.0 from 1934 to 1936 . Thus from 1929 into 1936 industrial production had declined in the U.S. by $30 \%$ (nearly a third less in output and in jobs).

From a cross-disciplinary perspective of economics (production) and sociology (classes) and anthropology (culture), the 1930s U.S. depression was not merely a large economic recession, it was a structural depression. In severe economic deflation, a societal structure changes into an 'industrially-depressed state (a structure characterized by lost wealth, excess industrial capacity and under-production, large unemployed class, political instability).

\section{Conclusions}

The conclusion of this research is that the meta-framework of societal dynamics analysis enables one to better explain the U.S. Great Depression, not in terms of causes, but as changes in societal stasis due to events which change society (change events). This historical perspective differentiates explanations into those of 'triggering events' (change events) of economic history and into those of altered states of a society, stasis in a societal model. The value of the research is in applying a broader cross-disciplinary framework in the analysis of history to better connect economic theory with economic history.

The limit of the research lies in its dependence upon previous economic histories of the depression and previous theories about explaining the depression. The paper does not do any original research on the history nor on the economic theories. The original contribution of the research is in the methodology of analysis of economic history and theory as a cross-disciplinary societal dynamic. 
Accordingly, the paper has analyzed this key economic drama as a change in societal stasis, due to crisis events. The crisis events were the stock market crash and its following bank panics, all triggered by the collapse of the large and highly-levered U.S. financial market of the late 1920s. In this cross-disciplinary framework, the historical analysis of the societal dynamics of economic instability is described as stasis changes. This approach is different from a purely disciplinary approach to trying to find a single explanation, a cause of a major economic change. The usefulness of this approach is to better understand and reconcile the divergences in the economic discipline about explanations of the decade. The U. S. economics discipline has divided into two schools because of their different emphasis on the importance in an economy of process (monetarists) or of structure (Keynesians). In explaining societal dynamics, a cross-disciplinary approach facilitates the balancing of process and structure, both of which are important to understanding a societal system.

The structure-functional approach to society was explored in the social science disciplines of sociology and anthropology. Talcott Parsons, who had advocated a structural-functional school in sociology, described a society as 'structure and function'. (Parsons, 1968) A social structure is the infrastructure in a society and function is what-the-infrastructure-provides. For example, an economic system in a society consists of an infrastructure in which economic production and trading of goods and services occur - providing an economic function for the society. Also at that time in anthropology, Franz Boas and Claude Levi-Strauss were two well-known advocates of a similar approach, but applied to non-industrial societies and therein called a 'culture'. (Boas, 1911) (Levi-Strauss, 1955) For them, all human cultures had similar 'underlying patterns of thought' in which social interactions (structure) were guided by practical meanings (function), which together constituted the culture of the primitive society.

What societal dynamics theory contributes to structural-functional thought is an analytical technique to systematically apply a general structural-functional analysis to any historical event. This analysis provides a strong argument for the social sciences to talk to each other. The long-running conflict in the economics discipline about the primacy of economic processes or structures is clearly resolvable -- within a balanced structural-functional perspective from the sociology and anthropological disciplines.

A societal dynamics approach to understanding economic dynamics can assist in the grounding of valid economic theory by providing a general cross-disciplinary framework for analyzing economic histories -- in order to compare history to theory. Future possible research will be to apply the cross-disciplinary analysis to U.S. regulatory reform and compare that effectiveness to bank panics after 1930.

\section{References}

Bernanke, Ben S. (1995). "The Macroeconomics of the Great Depression: A Comparative Approach", Journal of Money, Credit, and Banking, Vol. 27, No. 1, February. http://dx.doi.org/10.2307/2077848

Bierman, Harold J. (2010). "The 1929 Stock Market Crash"; Cornell University, Economic History Association [Online] Available: http://eh.net/encyclopedia/article/Bierman.

Calomiris, Charles W. \& Joseph R. Mason. (1997). "Contagion and Bank Failures During The Great Depression: The June1932 Chicago Banking Panic.” American Economic Review, December. 87(5), pp. 863-883.

Calomiris, Charles W. \& Joseph R. Mason. (2003). "Fundamentals, Panics, and Bank Distress During the Depression." American Economic Review, December. 93(5): pp. 1615-1646.

Fisher, Irving. (1933). "The Debt-Deflation Theory of the Great Depression." Econometrica, October 1933,

Friedman, Milton \& Anna J. Schwartz. (1963). A Monetary History of the United States, 1867-1960. Princeton, NJ: Princeton University Press.

Kindelberger, Charles P. \& Robert Z. Aliber. (2011). Manias, Panics, and Crashes: A History of Financial Crises. ( $6^{\text {th }}$ ed.) Palgrave Macmillan.

Minsky,Hyman P. (1975). John Maynard Keynes, Columbia University Press. (also McGraw-Hill, 2008)

Minsky, Hyman P. (1986). Stabilizing on Unstable Economy, McGraw-Hill (republished in 2008)

O’Neil, William D. (2009). The Great Depression in Facts and Figures. (www.analysis.williamdoneil.com)

Parker, Randall. 2010. "An Overview of the Great Depression," Economic History Association, February 5. (http://eh.net/encyclopedia/article/parker.depression)

Parsons, Talcott. (1937). The Structure of Social Action. (1967 edition, Free Press)

Richardson, G. (2007). "The Collapse of the United States Banking System during the Great Depression,1929 to 1933. New Archival Evidence,” Australasian Accounting Business and Finance Journal, 1(1). [Online] Available: http://ro.uow.edu.au/aabfj/vol1/iss1/4Richardson

Soros, George. (1988). The Alchemy of Finance (Simon \& Schuster, 1988) ISBN 0-671-66338-4 (paperback: Wiley, 2003; ISBN 0-471-44549-5.

Soros, George. (1994). "The Theory of Reflexivity", MIT Department of Economics World Economy Laboratory Conference, Washington, D.C., April 26. [Online] Available: http://www.george sorose website.

Temin, Peter. (1976). Did Monetary Forces Cause the Great Depression? New York: W.W. Norton. 